MEDDELANDEN FRÅN

SVENSKA HANDELSHÖGSKOLAN

SWEDISH SCHOOL OF ECONOMICS

AND BUSINESS ADMINISTRATION

WORKING PAPERS

508

Christian Grönroos

WHAT CAN A SERVICE LOGIC OFFER MARKETING THEORY 
What Can A Service Logic Offer Marketing Theory

Key words: Service marketing, marketing logic, relationship

(C) Swedish School of Economics and Business Administration, Christian Grönroos

\section{Christian Grönroos}

Department of Marketing

Swedish School of Economics and Business Administration

P.O.Box 479

00101 Helsinki, Finland

Distributor:

Library

Swedish School of Economics and Business Administration

P.O.Box 479

00101 Helsinki

Finland

Phone: +358-9-43133 376, +358-9-431 33265

Fax: +358-9-43133425

E-mail:publ@hanken.fi

http://www.hanken.fi/hanken/eng/page1579.php?

SHS intressebyrå IB (Oy Casa Security Ab), Helsingfors 2005

ISBN 951-555-875-1

ISSN 0357-4598 


\title{
What Can A Service Logic Offer Marketing Theory
}

\author{
Christian Grönroos*
}

December 2004

\begin{abstract}
The goods-dominated marketing model has major shortcomings as a guiding marketing theory. Its marketing mix approach is mainly geared towards buying and does not include consumption as an integral part of marketing theory. Although it is during the process of consuming goods and services that value is generated for customers and the foundation for repeat purchasing and customer relationships are laid, this process is left outside the scope of marketing.

The focus in service marketing is not on a product but on interactions in service encounters. Consumption has become an integral part of a holistic marketing model. Other than standardized goods-based value propositions can be better understood when taking a servicebased approach. It is concluded that marketing based on a goods logic is but a special case of marketing based on a service logic and applicable only in certain contexts with standardized products.
\end{abstract}

Key words: Service marketing, marketing logic, relationship

* CERS Center for Relationship Marketing and Service Management, Hanken Swedish School of Economics Finland, P.O.Box 479, FIN-00101 Helsinki, Finland, Phone: +358-9-431 331, E-mail: christian.gronroos@hanken.fi

Acknowledgement: The author would like to thank his colleague Tore Strandvik at Hanken Swedish School of Economics Finland for his useful comments and suggestions. 


\section{WHAT CAN A SERVICE LOGIC OFFER MARKETING THEORY}

\section{Introduction}

The purpose of this chapter is to discuss what a service logic can offer marketing theory. In services, interactions and relationships with customers are central phenomena, whereas traditionally exchange has been considered the core concept of marketing. According to this view value for customers is embedded in the exchange. The product that is exchanged includes value, and this value is delivered to customers for their use. As Vargas and Lusch (2004) have revealed this view of value seems to be based on a misunderstanding when macroeconomic analysis of value was transferred to microeconomics and from there further adopted by business economics. Value proposition is mixed up with value for customers. In reality, there is no value for customers until they can make use of a product. Value is not what goes into goods and services, it is what customers get out of them; i.e. value emerges in the customers' space rather than in the producer's space (Vandermerwe 1996). The notion that only customers can assess value to goods and services was expressed by Levitt (1983) already in the early 1980s. However, this thought was largely ignored by the academic and business communities alike. From the beginning of the 1990s onward this value-in-use notion (see Woodruff \& Gardial 1996), as opposed to a value-in-exchange view, has been put forward in the marketing and management literature (see, for example, Normann 2001, Storbacka \& Lehtinen 2001, Grönroos 2000, Gummesson 2002, Wikström 1996, Vandermerwe 1996, Woodruff \& Gardial 1996, Ravald \& Grönroos 1996, Jüttner \& Wehrli 1994, and Normann \& Ramirez 1993).

This value-in-use notion has been an implicit, if not explicitly expressed foundation of service marketing and relationship marketing. In service marketing the concept of interaction between the consumer and various resources and systems of the service firm was introduced as a core phenomenon. In relationship marketing this was extended to relationships over time, where a set of interactions take place. These may include product transfer, repair and maintenance activities, information, personal contacts, customer training, product upgrading, problem solving and service recovery and a number of other activities and processes. The relationship becomes the core of marketing. The firm should attempt to create relationships with its customers, because if that is not the case managing interactions successfully will be less easy and in the worst case no business takes place. In addition, a relationship approach to 
marketing makes it important for a supplier or service provider to manage a flow of processes aiming at making it possible for customers to perceive value in their consumption or usage processes; that is, to perform as service firms. What service firms do is to manage processes where interactions take place in order to make it possible for their customers to manage their own processes in a value-creating manner (value-in-use). It is no new observation that, especially when taking a relationship approach, all businesses are service businesses (see, for example, Webster 1994 and Grönroos 2000).

In order to understand the new role of marketing in a service business and relationship context it is important to start with an understanding of what should be achieved by marketing. In short the goals of marketing can be formulated in three steps (compare Grönroos 2000):

1. To get customers to buy a firm's goods or services a first time ("to get customers");

2. To provide these customers with such interactions with goods, services and other touchpoints with the firm so that they get satisfied enough with the value they get from using the goods or services to consider buying the same goods or services again from the same supplier or service provider ("to keep customers"); and

3. To further cultivate the interactions with these customers so that they give the supplier or service provider a larger share of not only their wallet but also of their heart and mind (Storbacka \& Lehtinen 2001), so that an emotional or attitudinal connection is established ("to grow customers").

Latent relationships between suppliers and customers always exist, but only when achieving the third goal relationships have been perceived and appreciated by customers; they have become manifested. And ultimately it is the customers who determine whether a relationship exists with a supplier or not. Relationship marketing requires that the firm aims at achieving the third goal, but in many cases the firm may not get further than to Goal 2. However, in principle for a manifested relationship to exist it is not enough with repeat buying behavior, an attitudinal component is also required. A firm can practise relationship marketing even though none of its customers, or only part of them, are at the third stage (Goal 3 reached), but relationship marketing as a strategy means that the firm attempts to reach the third goal. 
Repeat buying may be due to many other reasons than the existence of a relationship. Various bonds, such as geographical closeness, technological superiority or affordable price level, may make a customer buy the same goods or services over again from the same supplier or service provider, but as soon as an option with a more convenient location, better technology or more affordable price appears, the customer may be gone (Liljander \& Strandvik 1995 and Arantola 2002). Inertia, without an attitudinal connection, may also make customers behave in a relationship-like way. Bonded behavior of the above mentioned types and inertia must not be mixed up with relationships. However, repeat buying behavior does not have to be caused by negative bonds or inertia. If it is not, we have an at least partly manifested relationship. If, in addition to repeat purchasing behavior, there is an attitudinal or emotional connection between the customer and the firm, a well-manifested relationship probably exists and the likelihood that the customer will stay grows (Lindberg-Repo \& Grönroos 2004). It goes without saying that a relationship should be mutual. The supplier and service provider must also be committed to its customers. Relationship marketing is not a manipulative approach to marketing. Hence, a relationship in a commercial context can be defined as mutual understanding and commitment between two parties in the marketplace for the sake of supporting the customer's value processes and creating value for the supplier or service provider ${ }^{1}$.

A relationship is developed over time as a result of interaction and communication processes. In Figure 1 the content of these processes as well as their value-generating effects for the customer and the supplier or service provider, respectively, are illustrated (see Grönroos 2004).

\section{FIGURE 1 ABOUT HERE, PLEASE}

Customers are exposed to a firm's activities in two separate, yet related processes. In the figure these processes are illustrated by the two outer circles: the distinct communication process and the interaction process. The distinct communication process includes firmcustomer touchpoints that are purely communicational, including sales. Advertising, direct response communication, sales support activities and sales are examples of such activities.

\footnotetext{
${ }^{1}$ This definition of a relationship is based on a discussion of what constitutes relationships in a business-to-business context. See Håkansson, Håkan \& Ivan Snehota, Developing Relationships in Business Networks. Routledge: London, 1995.
} 
The interaction process represents the real world. Episodes in the interaction process are, for example, interactions with goods, service processes, web sites, call centers, service recovery procedures, payment and invoicing systems, documentation about how to use goods, etc. Activities in the distinct communication process are aimed at giving promises about the firm's value proposition, whereas the episodes in the interaction process should fulfil promises that have been given. The reality is, of course, more complicated than this. For example, competitor's actions and promises as well as how a customer interprets a communicational message and his or her mood and emotions at any point in time will influence promises given by a firm and the fulfilment of them.

Of course, interactions between the customer and the firm in various episodes also communicate something and gives promises, and may even include sales activities. However, the main objective of the episodes of the interaction process is to provide customers with value-supporting solutions (goods, services, information and when needed including service recovery, call center advice, etc.), i.e., solutions that support the customers' processes in a value-supporting way. The arrows between these two circles point out the need to integrate the communicational activities in the distinct communication process with episodes in the interaction process. When this integration has been achieved and both the firm and the customer has learned to listen to each other and respond to what they hear, communication in the marketplace may have developed into a relationship dialogue (Grönroos 2000).

The innermost circle illustrates the value-generating processes of customers as well as of the supplier or service provider. If the activities on the two outer circles develop favorably, value is generated in the customers' processes as well as created for the supplier or service provider. Hence, if performed well, activities and interactions in both the distinct communication and the interaction process contribute to customers' value creation and this, in turn, should pay back as more value for the firm and its shareholders.

\section{Basic "rules" of marketing}

Keeping in mind that marketing relates a firm to its customers, whatever is planned and implemented as part of marketing should have an impact on customers. This leads to a First basic "rule" of marketing: 
Marketing activities have to take place where the customers are and where the customers are influenced by them

This should be self-evident, but still this guideline is often violated. All variables of the marketing mix are geared towards achieving sales, whereas only one, Product, can be considered to be partly related the consumption of goods as well. It is mainly left to the customers themselves to decide whether consumption, which is treated as a black box, influences their willingness to do repeat purchases. In spite of this, it is during consumption customers assess the value-supporting capacity of goods (and services) for them. To a decisive degree the foundation for future buying behavior is laid here. However, instead of making the consumption process a marketing arena, it is treated as a black box. The goods as such including add-ons such as warranties and documentation (the Product variable) may not provide enough incentive for a customer to buy again. Customer satisfaction is a key concept in marketing, but what really takes place in the customers' processes when using goods remains unknown and outside the scope of marketing. Branding, to a large degree based on marketing communication, the Promotion variable, is offered as a way of increasing the attractiveness of products. However, branding goods that do not support customers' consumption processes in a value-generating way is an uphill battle, where the marketing budget is under constant upward pressure and the productivity of marketing decreases.

In service firms that are influenced by consumer goods-dominated marketing models marketing in practice is often dominated by marketing communication. These communicational activities may, of course, influence the customers, but in addition the customers are engaged in a number of service processes (service production and delivery processes), which are not managed with a customer focus, i.e., with a marketing concern. The customers are in the service production and delivery processes, but most often marketing is not there.

Hence, goods-dominated marketing models make firms put their marketing efforts only partly in places where their customers are. Consequently, marketing effectiveness can be expected to be lower than it could be. It should be noted that what here is called "marketing activities" not only refer to what is included the marketing mix or to activities that are planned and managed by the marketing department. In principle, anything could be marketing activities as long as 
these activities take place in contexts where they are observed and perceived by customers and influence them.

According to the marketing concept, the customers are at the center of marketing. This leads to a Second basic "rule" of marketing:

The customers of a firm, not its marketing department, decide which of the firm's resources and activities are marketing resources and activities

If marketing should take the customers and their needs and wants as the starting point for developing marketing activities, it is only these customers who can decide what marketing of a given firm consists of. This guideline is also often violated. To take a service example, the customers would probably like the service processes to be smoother, including for example better interactions with service contact employees, whereas the firm's marketing activities are elsewhere, mainly in the form of advertising campaigns and price offers.

\section{Shortcomings of the consumer goods-dominated marketing logic}

Based on the value-in-use assumption, the consumption or usage behavior of customers and their internal value-generating processes become an area of interest for marketers and marketing. If they are not integrated into marketing, only getting customers (Goal 1 above) can be successfully achieved, whereas keeping and growing customers (Goals 2 and 3) will be given less organized attention or more or less totally forgotten. As relationship marketing demonstrates, keeping and growing customers are at least as vital to success as getting customers. In addition it is important to keep in mind that while a manipulative marketing approach can make some customers buy a first time, in other cases customers may not even make a trial purchase before the firm has won their mind and perhaps even their heart.

The goods-dominated marketing logic has drawn buying and consuming apart. Marketing models and the consumer goods-inspired marketing mix revolves around getting customers to buy. Only the Product variable is somehow related to consuming or using goods, but even this variable is in marketing models almost totally geared towards making customers buy. Clearly this is a serious shortcoming in marketing of today, where long-term relationships become more and more important for firms to develop. And even if such relationships are not 
considered imperative to a firm's success on the marketplace, no firm can survive in the long run without repeat purchases by a considerable number of its customers. Today marketers are persuading customers to buy again mainly by marketing communication and price offers. The goods-dominated logic of marketing does not seem to offer other opportunities. The main reason for this is that this logic does not properly include consuming and the customers' processes as an integral part of its models. Explicitly it only deals with buying.

It seems quite obvious that keeping buying and consuming apart has had negative effects on marketing. Because the consumption process goes unsupported by the firm, this separation of buying from consuming easily has a negative impact on customers' internal value-generating processes and on customer satisfaction. Moreover, it has led to unnecessarily high marketing costs and revenue losses caused by too much money spent on marketing communications and by unnecessarily huge price offers.

Keeping buying and consuming apart does not mean that consuming would not have been an area of interest for marketing research. On the contrary, there is a considerable literature on consumer behavior, but the problem seems to be that this literature is not clearly related to the consumer goods-based theory of marketing with its marketing mix and $4 \mathrm{P}$ model. One could say that marketing is marketing and consumer behavior is consumer behavior, and the two do not meet.

\section{A service-based logic: The Nordic School approach}

Service marketing research has addressed the importance of customers' consumption processes in a different way. This is, for example, demonstrated by the interest in studying the service encounter and perceived service quality. There is a considerable amount of research that ties together the buying and consuming processes and hence gears marketing to the valuegenerating processes of customers. In North America for example the $7 P$ extension of the marketing mix is an attempt to include company resources such as people, processes and physical resources (physical evidence) in a marketing model (Booms \& Bitner 1982). These variables clearly relate to the service production/consumption interface. In France a service marketing model, the Servuction model (Langeard \& Eiglier 1987), also recognized the importance to integrate marketing with the consumers' processes. 
Another approach to service marketing which explicitly integrates buying, consuming and marketing is the Nordic School of service marketing thought emanating out of the Nordic countries of Europe, Scandinavia and Finland (see Berry \& Parasuraman 1993, Gummesson, 1977, Grönroos 1978 and Grönroos \& Gummesson 1985). One of the central arguments of the Nordic School, which was developed already from the mid-1970s, is that the interactions between the service provider (an organization with people, physical resources and systems) and the consumer of its services during the simultaneous service production and consumption processes are at the heart of successful marketing. Marketing was divided into an external marketing part, including some traditional elements of the marketing mix such as marketing communication and pricing, and an interactive marketing part, which was geared to the interactions that take place when customers and various resources of the firm, such as people, systems and physical resources and goods, meet during the consumption of services. (Thus, the interactive marketing term, which now has become popular in the context of interactive media, was originally introduced in service marketing research.) Also, an interest in understanding how customers perceive the service process and its outcome grew, resulting in the perceived service quality model published in the early 1980s (Grönroos 1983 and 1984).

Although value was not explicitly discussed in the 1970s, implicit in the Nordic School of service marketing thought was a value-in-use concept, where the interactions between service providers and customers was considered the core of marketing, not exchange of preproduced service products. Value is created by the customer in interactions with the service provider and supported by the service provider. In addition to this the outcome of the service production process when used by the customer also contributes to customer value.

Making the management of the interactions between the service firm and its customers (the service encounter) a field of interest for marketing made consumption of a service an equally important marketing issue as buying services. Thus, the black box of consumption was opened up and explored. From a marketing point of view, consuming services was seamlessly integrated with buying services. Interactive marketing is the part of total marketing that is geared towards managing the consumption process in a value-supporting way, in order to increase the likelihood that the customers decide to stay with the firm.

In Figure 1 the beginning of the distinct communication and the interaction process were indicated in an arbitrary way. In reality it is difficult to determine when consumption and 
customers' value creation starts and ends. For example, depending on how broadly consumption is defined, the consumption of an inclusive tour to a tourist destination may begin already when the customer starts thinking about doing the trip, or when the first interaction with an ad by the tour operator is seen. By the same token, the customer's value creation may start from the very beginning of this extended consumption process or at least at the point in time when he or she starts thinking about and reviewing the tour operator's options. There is, so to speak, a mental pre-consumption even before interactions with the tour operator's processes commence. Also, it may be difficult to determine when consumption ends. A similar mental post-consumption may take place. Using the inclusive tour example, one could say that consumption does not end when the customer returns home, but when memories of the trip are not brought up in discussions or entering the person's mind anymore.

When both buying and consuming are managed as marketing issues, it is easier to reach all three goals of marketing, i.e., getting customers, keeping customers and growing customers, and in the best case ultimately create manifested relationships with customers. In addition, when marketing is explicitly extended to the consumption process (interactive marketing), the two basic "rules" of marketing are better appreciated. All resources needed in the interactions with customers during the integrated buying and consumption processes, irrespective of which department they belong to, can be developed and managed with a customer focus ("Rule One"). Otherwise they easily are thought of and managed as operational sources only (which they of course also are). A customer focus in the service encounters also forces the service firm to get and use customer input into how the service encounters should function from a marketing perspective in order to make customers interested in repeat purchasing ("Rule Two").

In conclusion, according to this logic the service provider should develop such a set of resources and create such interactions with its customers that these interactions between the firm and its customers, together with the outcome of the service process, have a positive impact on the customers' value creation. This increases the likelihood of repeat purchasing, and perhaps contributes to the development of relationships between the service provider and its customers. The role of external marketing activities is to get customers, whereas the role of interactive marketing is to keep and grow customers and in the best case to lay the foundation for enduring customer relationships. 
The logic of service is to support the customers'value-generating processes. And due to the importance of the interactions between the service provider and its customers, marketing's role is not only to communicate value propositions but to make sure that value indeed is created in the customers' processes.

\section{What can a service logic offer goods?}

The service logic discussed in the previous section can be summarized in the following way:

1. Because value for customers is created when they consume a service, i.e., in the customers' value-generating processes (value-in-use), the role of the service provider is to support the customers' processes with a set of resources - service employees, systems, physical resources, and the customers themselves and the time they spend in interactions - as well as with service processes and interactions that contribute to value creation in those processes. The logic of service is to support customers' processes so that value for the customers is created in those processes. Consequently, services can be defined as processes where a bundle of resources are integrated to support customers' processes in order to enable value creation in those processes.

2. Although some of the consumption of a service takes place in isolation from the production and delivery of that service, the consumption process is an integrated part of service production and delivery (the service process).

3. Because the simultaneously occuring part of consumption and production of a service has a decisive impact on the customer's perception of the quality of the service (especially on the functional or process quality dimension) and therefore also on the attitudes of customers towards the service provider and on their future purchasing behavior, in order to reach all three goals of marketing, managing and handling activities in the consumption process have to be an integral part of the total marketing process of the service provider (interactive marketing as part of total marketing).

Let's examine the case of physical goods in the light of the above summarized service logic. As a means of illustration cellular phones will be used. The same arguments can easily be made for any type of goods. 
1. The reasons for using cellular phones are several: communicating with other people, entertaining oneself in isolation or even together with someone else, taking photographs and perhaps sending them to someone else, doing financial transactions, paying for bus tickets, car wash and car parking, sending and receiving e-mails, etc. According to the value-in-use notion customers consider that they get value in their processes of communicating, playing games, making payments, reading and sending e-mails and operating on the Internet when the cellular phone indeed facilitates doing so in a secure, uncomplicated and swift manner. If all these functions do not work properly, a cellular phone with all technical capabilities for performing all these functions is not enough. No support to customers' value creation exists. What is required is call center and customer service activities, access to entertainment content, an infrastructure with connections to telecommunication operators, financial institutions and other organizations that enables the performance of the functions technically made possible by the cellular pone itself. Some of these activities, for example call center and customer service and entertainment content can be provided by the manufacturer of the cellular phone, whereas others have to be offered by others in a network context.

2. Making it possible for customers to use/consume a cellular phone for some or all of the above mentioned activities is clearly in the best interest of the producer of the phone; otherwise the phone is less useful than it could be. Making sure that, for example, customer service is prepared to give proper advice about how to use the phone, that games and other forms of entertainment are easily accessible and that the Internet connections work so that customers continuously can use the phone are critical to customers' value creation. Some of these resources and interactions are provided by the manufacturer of the cellular phone, whereas others are the responsibility of other organizations. All are required so that customers can use the phone in ways they want, and they have to be available at the very moment the customers need them and try to make use of them.

3. If a cellular phone does not have the technical capability and is not backed up by necessary customer service support or if telecommunication operators and other organizations do not support the use of the existing technical capabilities of the phone in a proper way, customers will shift to other manufacturers which offer more appropriate technical capabilities and support from its own organization and other organizations needed to make value creation possible in the customers' processes. 
Repurchasing will not take place, bad word-of-mouth will probably occur. In other words, marketing has failed to keep and grow the customers of the firm (reaching Goals Two and Three of marketing). And if that is the case, marketing as such has failed.

Even in the case of goods customers are looking for service. They are spending money and time to make it possible to make use of goods for the service they get from a bundle of goods and necessary supporting resources required to use these products. The support to their valuegenerating process that they get from the physical product combined with other required resources is the service. In the case of cellular phones these "other required resources" were, for example, call center customer service support, access to entertainment content, support from telecommunication operators and other organizations needed to use technical capabilities offered by a cellular phone.

\section{Conclusions}

Two conclusions can be drawn from the discussion of what a service logic can offer the marketing of goods:

First of all, concentrating on the product draws the marketers attention away from what ultimately is important for the customers, their value-creating processes. The goods are considered the value, when in reality they are only value support. It also makes the marketer believe that the goods are the key and often also only source of value for customers, when in fact they perhaps are not even the most important ones. As the case of cellular phones demonstrates, the phone is only a starting point for customers' value creation, but the rest of the resources are the ones which makes it possible for the customers to create value in their processes.

In conclusion, goods are one resource among others in a bundle of resources, consisting of goods and other tangible items, service employees, systems, processes and the customers themselves and interactions between these resources, that are needed to make it possible for customers to create value for themselves. In other words, this bundle of resources, where the goods are nothing but one resource among others, is required to support the customers processes so that value is created in those processes. The observant reader realizes that this is 
a description of a service and of the logic of service. In this respect the cellular phone is equivalent to the beef in a hamburger restaurant. The beef has to be there, and it has to fulfil given requirements, but without the other resources of the restaurant no restaurant service will exist. The beef will not be bought and consumed. Hence, goods are resources, goods businesses are service businesses, and the marketing of a physical good should be viewed as marketing of a service.

Secondly, although cellular phones were used as illustration, the same analysis can be made for any type of goods. In order for the customer to use goods, other resources have to accompany them, and the goods are only one resource among others in the process of supporting customers' value-generating processes. However, there are of course situations where a good is of such a nature that, based on a customer's level of competence, it is so simple to use that no support in terms of customer service, customer education or support from other organizations are required. The only resources that are needed are the goods and the customer. Of course, another customer with a lower level of competence may need such support. Buying candy could be an example of a situation where few customers would need additional support. The only resource customers interact with and is required so that they can create value in their processes is the good. In this case, focusing on the physical product only, in addition to the customer, as the means of customers' value creation can work well, and a marketing approach where the physical product is the only variable which is related to the customers' consumption processes can be successful.

However, in a situation as the one described above, the physical product is still a resource required to support the customers' processes. The only thing that differentiates this situation from the case of cellular phones is that no other resources are required. It is still a matter of spending customers' money and time for the support of their processes that this good as a resource can offer. Hence, it is still a matter of spending money and time for a service. In conclusion, goods marketing is a special case of service marketing; a case where the interactions with customers is solely related to the goods. In this case focusing predominantly or only on the product variable as a means of supporting customers' processes can lead to a positive results in terms of marketing. But this is only a special case. And even in this case customers are looking for support to some processes of theirs; that is, they are looking for the service the product as a resource can produce. 


\section{References}

Arantola, Heli (2002): Relationship Drivers in Provider-Consumer Relationships. Empirical studies of customer loyalty programs. Diss., Helsingfors: Hanken Swedish School of Economics Finland

Berry, Leonard L. \& A. Parasuraman (1993): Building a new academic field - the case fo services marketing. Journal of Retailing, 69, 1, 13-60

Booms, Bernard H. \& MaryJo Bitner (1982): Marketing Structures and Organization Structures for Service Firms. In Donnelly, John H. \& William R. George, eds., Marketing of Services. Chicago, IL: American Marketing Association

Grönroos, Christian (1978): A Service-Oriented Approach to the Marketing of Services. European Journal of Marketing. 12, 8, 588-601

Grönroos, Christian (1983): Strategic Management and Marketing in the Service Sector. Report 83-104. Cambridge, MA: Marketing Science Institute

Grönroos, Christian (1984): A service quality model and its marketing implications, European Journal of Marketing, 18, 4, 36-44

Grönroos, Christian (2000): Service Management and Marketing. A customer relationship management approach. Chichester, UK: John Wiley \& Sons

Grönroos, Christian (2004): The relationship marketing process: communication, interaction, dialogue, value. Journal of Business \& Industrial Marketing, 19, 2, 99-113

Grönroos, Christian \& Evert Gummesson (1985): The Nordic School of Services - An Introduction. In Grönroos, Christian \& Evert Gummesson, eds., Service Marketing - Nordic School Perspectives. Series R:2, Stockholm University

Gummesson, Evert (1977): Marknadsföring och försläljning av professionella tjänster (Marketing and sales of professional services). In Swedish. Stockhom: Akademiförlaget 
Gummesson, Evert (2002): Relationship marketing and a new economy: it's time for deprogramming. Journal of Services Marketing. 16, 7, 585-589

Håkansson, Håkan \& Ivan Snehota (1995): Developing Relationships in Business Networks. Routledge: London

Jüttner, Uta \& H.P. Wehrli (1994): Relationship Marketing from a Value Perspective. International Journal of Service Industry Management, 5, 5, 54-73

Langeard, Eric \& Pierre Eiglier (1987): Servuction. Le marketing des services. Paris: John Wiley \& Sons

Levitt, Theodore (1983): The Marketing Imagination. New York: The Free Press

Liljander, Veronica \& Tore Strandvik (1995): The Nature of Customer Relationships in Services. In Swartz, Theresa A, David E. Bowen \& Stephen W. Brown, eds., Advances in Services Marketing and Management, 4, Greenwich, CT: JAI Press, 141-167

Lindberg-Repo, Kirsti \& Christian Grönroos (2004): Conceptualising communication strategy from a relationship perspective. Industrial Marketing Management, 33, 229-239

Normann, Richard (2001): Reframing Business. When the Map Changes the Landscape. Chichester, UK: John Wiley \& Sons

Normann, Richard \& Rafael Ramirez (1993): From Value Chain to Value Constellation:

Designing Interactive Strategy. Harvard Business Review, July-August, 65-77

Storbacka, Kaj \& Jarmo R. Lehtinen (2001): Customer Relationship Management. Singapore: McGraw-Hill

Vandermerwe, Sandra (1996): Becoming a Customer "Owning” Company. Long Range Planning, 29, 6, 770-782 
Vargo, Stephan L. \& Robert F. Lusch (2004): Evolving to a new dominant logic for marketing. Journal of Marketing, 68 (January), 1-17

Webster, Jr., Frederick E. (1994): Executing the New Marketing Concept. Marketing Management, 3, 1, 9-18

Wikström, Solveig (1996): Value Creation by Company-Consumer Interaction. Journal of Marketing Management, 12, 359-374

Woodruff, Robert B. \& Sarah Gardial (1996): Know Your Customers - new approaches to understanding customer value and satisfaction. Oxford: Blackwell Publishers 
Figure 1. Customer-Firm Touchpoints

(Source: Adapted from Grönroos, Christian 2004): The relationship marketing process: communication, interaction, dialogue, value. Journal of Business \& Industrial Marketing, Vol. 19, No. 2, 106)

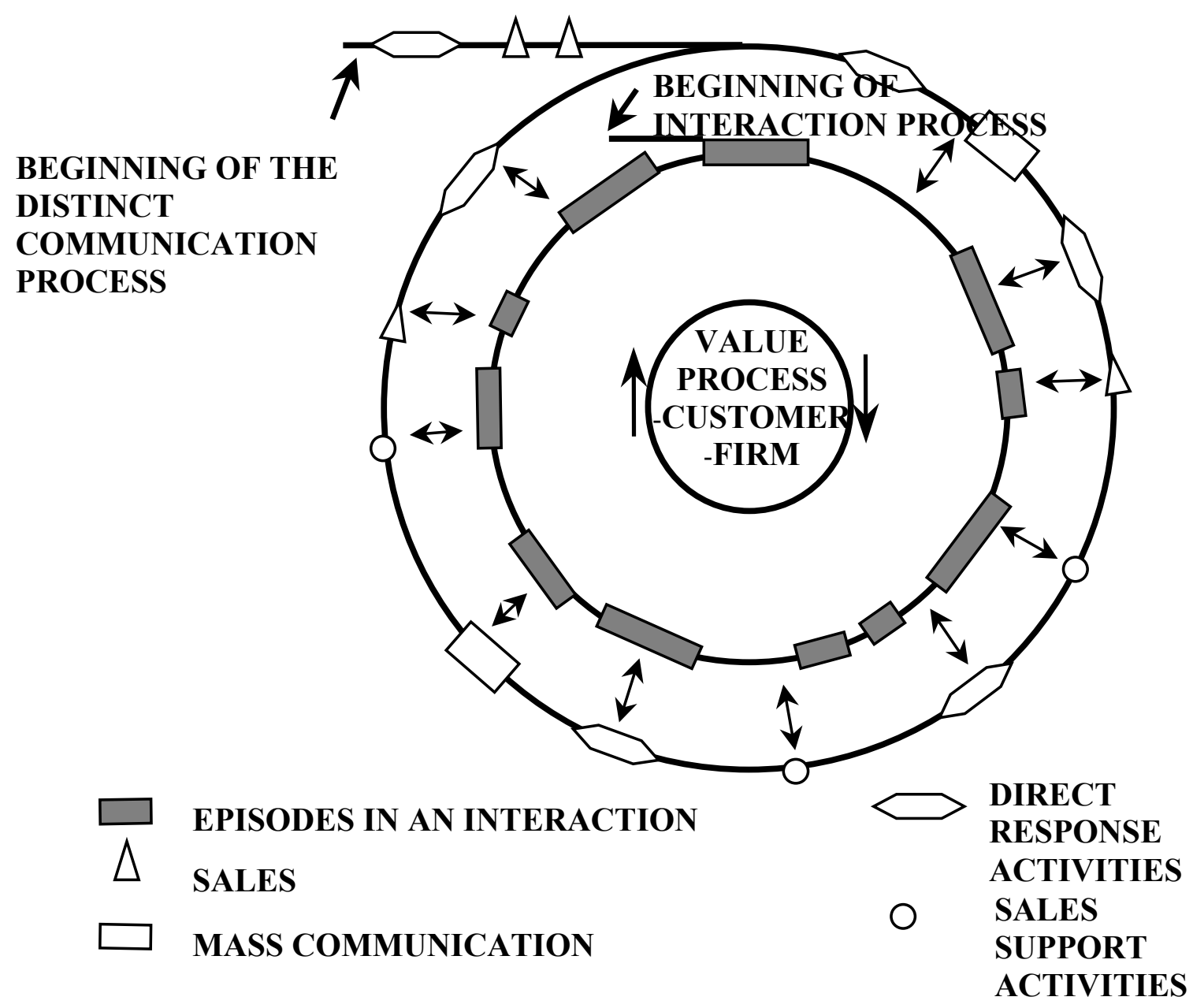




\section{Meddelanden från Svenska handelshögskolan}

\section{Swedish School of Economics and Business Administration. Working Papers.}

488. Nordman, Jan \& Liljander, Veronica: Mobile Service Quality - A Study of Contributing Factors.

489. Li, Hongzhu: Systematic Conditional Market Volatility.

490. Li, Hongzhu: Higher Moments and Asset Pricing.

491. Li, Hongzhu: ARCH Effects and the Conditioning Information Variables.

492. Arranz-Aperte, Laura \& Heshmati, Almas: Determinants of Profit Sharing in the Finnish Corporate Sector.

493. Ekholm, Bo-Göran \& Wallin, Jan: Shareholder/Stakeholder Value Management, Company

Growth and Financial Performance: An Exploratory Study.

494. Forsman, Maria \& Solitander, Nikodemus: Network Knowledge Versus Cluster Knowledge -The Gordian Knot of Knowledge Transfer Concepts.

495. Tallberg, Teemu: Networks, Organisations and Men: Concepts and Interrelations.

496. Rosenberg, Matts: Stock Option Compensation in Finland: an Analysis of Economic Determinants, Contracting Frequency, and Design.

497. von Nandelstadh, Alexander \& Rosenberg, Matts: Corporate Governance Mechanisms and Firm Performance: Evidence from Finland.

498. Pasternack, Daniel \& Rosenberg, Matts: What Determines Stock Option Contract Design?

499. Ahlgren, Niklas \& Nyblom, Jukka: A General Test for the Cointegration Rank in Vector Autoregressive Models.

500. Ahlgren, Niklas, Sjöö, Boo \& Zhang, Jianhua: Panel Cointegration of Chinese A and B Shares.

501. Karakozova, Olga: Modelling and Forecasting Office Returns in the Helsinki Area.

502. Fougère, Martin: Finnish-French Fundamental Cultural Antagonisms in Organising.

503. Pöllänen, Kari: Luottamusmiesten Sitoutuminen Yritykseen ja Ammattijärjestöönsä.

504. Fougère, Martin: Organizing (with) Thirdness. A Dialogic Understanding of Bicultural Interactions in Organizations.

505. Ekholm, Anders \& von Nandelstadh, Alexander: Do Analysts Leak Information to Preferred Customers?

506. Forsman, Maria \& Solitander, Maria: The Context and Diffusion of Knowledge in the Finnish Jewellery Industry - The role of The House of Fabergé.

507. Ekholm, Bo-Göran \& Wallin, Jan: Strategic Priorities, Company Performance and Attitudes Towards Management Accounting Techniques:an Empirical Study. 